\title{
The zoomorphic representations of the Pîrî Reis map (1513)
}

\author{
Marco MASSETI \\ Laboratori di Antropologia ed Etnologia, \\ Dipartimento di Biologia dell'Università di Firenze, \\ Via del Proconsolo 12, 50122 Firenze (Italia) \\ marco.masseti@unifi.it \\ Cecilia VERACINI \\ ISCSP - CAPP University of Lisbon \\ Rua Almerindo Lessa, 1300-663 Lisbon (Portugal) \\ cveracini2011@gmail.com
}

Published on 24 June 2016

KEY WORDS

Cartography,

iconography,

animals,

fabulous creatures,

$16^{\text {th }}$ century.

Masseti M. \& Veracini C. 2016. - The zoomorphic representations of the Pîrî Reis map (1513). Anthropozoologica 51 (1): 41-54. http://dx.doi.org/10.5252/az2016n1a3

\section{ABSTRACT}

In 1513 the famous Turkish navigator, geographer and cartographer, the admiral Pîrî Reis, drew a large planisphere showing the entire known world of the time. Today only a fragment of this work remains, conserved at the Topkapi Sarayi Museum in Istanbul (Turkey) and referred to as the Carte de l'Atlantique. This map represents one of the most controversial, mysterious and beautiful documents in the history of cartography. The aim of this study is to analyse the zoomorphic representations of the Pîrî Reis map, investigating the sources of their iconography as well as focusing on their zoological and cultural meanings. We carried out a review of existing literature on this topic, attempting to provide an updated scientific interpretation of the animals portrayed, considering the zoological knowledge assumed to exist at the beginning of the $16^{\text {th }}$ century and the probable cultural background of Pîrî Reis. Our interpretation demonstrates that many of the animals represented in the Pîrî Reis map conform to the European and Near-Eastern late medieval iconographic tradition. On the other hand, other zoomorphic representations, such as Caribbean parrots, appear unrelated to any previous source and could possibly have been copied from Columbus' lost map. 


\section{MOTS CLÉS \\ Cartographie, \\ iconographie, \\ animaux, \\ créatures fabuleuses, 16 ème siècle.}

\begin{abstract}
RÉSUMÉ
Les représentations zoomorphiques de la carte de Pîrî Reis (1513).

En 1513, le célèbre navigateur, géographe et cartographe turc, l'amiral Pîrî Reis, a dessiné un large planisphère figurant la totalité du monde connu de l'époque. Actuellement, seul subsiste un fragment de ce document, conservé au Musée Topkapi Sarayi d'Istanbul (Turquie) et désigné comme la Carte de l'Atlantique. Cette carte représente un des plus controversés, mystérieux et magnifiques documents de la cartographie. Le but de cette étude est d'analyser les représentations zoomorphiques de la carte de Pîrî Reis, en cherchant les sources de leur iconographie et en détaillant leurs significations zoologiques et culturelles. Nous avons réalisé une recension de la littérature existante sur ce sujet, essayant de donner une nouvelle interprétation scientifique des animaux dépeints en prenant en compte la connaissance zoologique présumée au début du 16ème siècle ainsi que la probable formation culturelle de Pîrî Reis. Notre interprétation démontre que beaucoup des animaux représentés sur la carte de Pîrî Reis sont conformes à la tradition iconographique de la fin du Moyen-Âge en Europe et au Proche-Orient. D’un autre côté, certaines des représentations zoomorphiques, comme les perroquets des Caraïbes, ne semblent provenir d'aucune source connue et pourraient avoir été copiées à partir de la carte perdue de Christophe Colomb.
\end{abstract}

\section{INTRODUCTION}

In 1513 (Islamic year 919), the admiral Pîrî Reis or Muhyiddin Pîrî Bey (1470-1553), the famous Turkish navigator, geographer and cartographer who is also known as the author of the Kitab-I Bahriye, the oldest guide book to the Aegean and the Mediterranean seas (see Zekâi Ökte \& Duran 1988), created a map (Fig. 1), the so-called Carte de L'Atlantique $(90 \times 65 \mathrm{~cm})$, now conserved at the Topkapi Sarayi Museum in Istanbul, Turkey (Reis 1513). Pîrî Reis began his career as a navigator at an early age with his uncle Kemal Reis, a famous commander of the Ottoman navy. At that time the Ottoman Empire was at the peak of its military power and in 1517 Pîrî Reis presented the map to Sultan Selim, conqueror of Egypt (Zekâi Ökte \& Duran 1988; Soucek 2013). This map is what remains of a larger planisphere showing the entire known world of the time. The fragment housed at the Topkapi Museum contains only part of the Iberian peninsula, the Bay of Biscay and the part of Africa west of zero degrees longitude, as well as the Atlantic Ocean and the parts of the Caribbean Sea and the American continent then known (Zekâi Ökte \& Duran 1988). This map is one of the most controversial, mysterious and beautiful documents in the history of cartography, not only because it reveals the extreme precision of the mapmaker, with a good level of accuracy in the positioning of the continents (Soucek 1992), but also because it could be a copy of the oldest map of America created by Christopher Columbus which is now lost (Kalhe 1933; Afetinan 1987; McIntosh 2000). The enigmatic representation of what seems to be the Antarctic coast (which had not yet been discovered when the map was made) gives a mysterious aura to this chart (Hancock 1995). However, following extensive study (see McIntosh 2000), the map appears less enigmatic and fairly consistent with the knowledge of the time. The admiral Pîrî Reis added to the map numerous notes and an extensive key which provide a wealth of information about his sources. The inscriptions on the map are in Arabic script; the language used (with one exception) is Ottoman-Turkish (McIntosh 2000). In the introductory part of the map Pîrî Reis wrote:

"In this age, no one has seen a map like this. The hand of this poor man [i.e. Pîrî Reis] has drawn it and completed it from twenty charts, and yappamundos [i.e. mappaemundi]. The latter derive from a prototype that goes back to the time of Alexander the Great (Iskender Zulkarneyn), which show the inhabited quarter of the world. The Arabs name these charts (dja'fariye) Jaferya. From eight Jaferyas of that kind and one Arabic map of Hint [i.e. India], and from four newly drawn Portuguese maps which show the countries of Sint, Hint and China geometrically drawn, and also from a map of the western region drawn by Qulunbu [i.e. Columbus]. I have brought all these sources to one scale, and this map is the result. In other words, just as the sailors of the Mediterranean have reliable and well-tested charts at their disposal, so the present map is correct and reliable for the Seven Seas" (Kalhe 1933; McIntosh 2000; Soucek 2013).

The chart drawn by Columbus that Pîrî Reis claimed to have used was apparently found in a Spanish ship captured by the Turks (Kahle 1933) and referred to the Central America and Caribbean regions discovered by the Italian navigator (McIntosh 2000). Pîrî Reis also acquired considerable information about the New World from Portuguese navigators, who are frequently mentioned in the notes to the map (Kalhe 1933).

In the $15^{\text {th }}$ century the best-known map was that of Claudius Ptolemy (c. 90-c. 168 AD), illustrating Greek knowledge of the world around $150 \mathrm{AD}$. In Europe the first printed edition of the map was produced in Bologna in 1477, and then in Rome in 1478, and in Florence in 1482 (Campbell 1987). Although out of date at the time of these later printings, Ptolemy's picture of the world with its coordinate system was regarded as a model at the time (La Roncière \& Mollat du Jourdin 1984). 


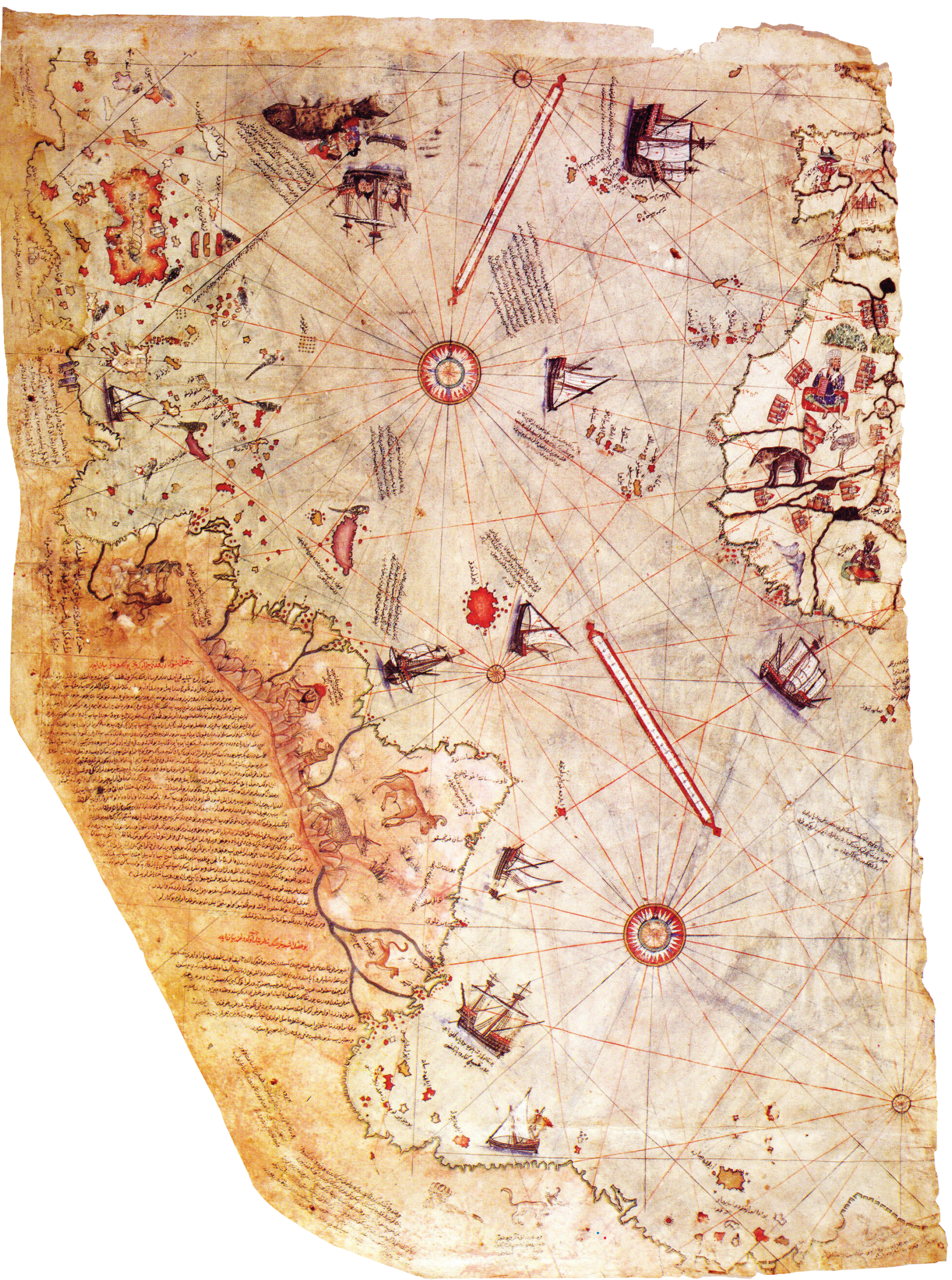

FIG. 1. - Carte de L'Atlantique, or "Pîri Reis World Map" (1513). Parchment, 90 ×63cm. Library of Topkapi Sarayi Muzesi, Istanbul. 
Arab geography was primarily a continuation of Greek and Roman scholarship. In the Middle Ages, Muslim scholars continued and improved the mapmaking traditions of these earlier cultures. Most used Ptolemy's methods, but they also took advantage of what explorers and merchants learned in their travels across the Muslim world, from Spain to India to Africa and beyond, and in trade relationships with China and Russia (Edson \& Savage-Smith 2004). In the early 16th century, the new geographical discoveries of the day, notably those of the Portuguese on the route to India and the New World, were added to modern maps. Philosophical ideas about the world were also woven into the fabric of the map. World maps were in fact a vehicle for displaying geographical, scientific, ethnographical and historical information, with drawings illustrating concepts of the physical world and the human environment. Geographical maps were based on symbolic representations, sometimes adapted to the exigencies of particular nations. In such maps, many things that are not credible and many oddities fill the spaces of the oceans and the empty spaces of the continental terra incognita. Certain tales dating back to medieval bestiaries or classical myths are at the origin of the representation of mysterious islands, sea monsters, fantastic animals and other incredible creatures on maps (see for instance Hassig 2013, for a review of the influence of medieval bestiaries and the classics on European myths). The $13^{\text {th-century "Hereford }}$ mappa mundi" (see Haldingham and Lafford c. 1300) is one of best-known examples of such understanding of the known world in mediaeval Europe, illustrating not only the human world of men, cities and seas, but entire bestiaries of horrifying mythical creatures and the strange cultures of distant lands. The survival of these legends in the portolan maps has been justified by the confusion between astrology and astronomy, and the libraries of the cartographers were filled with such treatises (La Roncière \& Mollat du Jourdin 1984). Like other charts of the same period, the Pîrî Reis map is enriched by the representation of several zoomorphic figures, real and fantastic, evoked for the specific designation of the various individual territories. Despite the fame of this map, to date no review of the iconographic meaning and scientific interpretation of all the animals represented has been published. Sporadic interpretations of some of these representations can be found in certain critical studies, but in general they have never been considered the subject of zoological research (e.g., parrots or monkeys), but simply as a means towards a better comprehension of the map itself. Such an analysis is important for the history of cartography and of art, but also for developing an understanding of the perception of the new worlds in the early Modern Era. The animals depicted on the maps can offer significant insights into the sources, influences and methods of the cartographers who drew or painted them (Van Duzer 2013).

\section{AIMS AND METHODOLOGY}

The aim of this research is to analyse the zoomorphic representations in the chart of Pîrî Reis, investigating the sources of their iconography as well as focusing on their scientific and cultural meanings. Starting from a review of previous interpretations of the zoomorphic depictions of the Pîrî Reis map (Kalhe 1933; McIntosh 2000; Pinto 2012), we compare the current zoological acquisitions to what we can assume to have existed at the beginning of the $16^{\text {th }}$ century. We also consider the cultural background of Pîrî Reis, his experience of the Atlantic world and the probable sources that could have been at the origin of the animal representations in the map, taking into account the iconographic traditions of both the Islamic/Near-Eastern and the Western world. For each zoomorphic representation we record the iconographic interpretations made by previous authors, the probable origin in relation to the assumed knowledge of Pîrî Reis (also considering his biography), the historical context of the animal, the associated myths and legends, and its interpretation according to current scientific knowledge. Our interpretation is focused on the zoological acquisitions of early Modern times and is not intended as a new interpretation of the map from a cartographic point of view, although our contribution might be used to validate some issues. This study devotes particular attention to the image/text interface. This interface is particularly important because - as observed by Pinto (2012) - "early Modern maps involve an intricate layering (or collage) of text and image derived from other works." For the interpretation of Pîrî Reis' notes on the map, we used the translation from Arabic to English published by Kalhe (1933), Afetinan (1987) and McIntosh (2000). We compared these translations, using the version shared by the majority of these authors, although there are no significant differences between them.

\section{ICONOGRAPHIC ANALYSIS OF THE PÎRÎ REIS ZOOMORPHIC REPRESENTATIONS}

\section{North Central Atlantic Ocean}

In the part of the map corresponding to the present-day North Central Atlantic Ocean, near the top northern edge of the drawing, there is only a very large fish together with a ship identified as a carrack by Soucek (2013). The fish carries on its back two human beings, who plausibly appear to be in the act of lighting a fire. The animal is, however, not a representative of the Pisces taxonomic order, but a type of whale (Mammalia) evoked in accordance with the tradition of the bestiaries (see McIntosh 2000; Van Duzer 2013) (see Fig. 2). Pîrî Reis' inscription referred to the whale as follows:

"It is said that in ancient times a priest called Sanvolrandan travelled through the Seven Seas. He is said to have come across this fish, to have landed on it, thought it was dry land, and lit a fire on this fish. When the back of the fish began to burn, it plunged under the water. The people fled in the boat and came to the ship. These things are not reported by the Portuguese infidels. It is taken from ancient mappaemundi" (McIntosh 2000).

The famous incident from the semi-legendary voyage of the Irish monk St. Brendan (also known as St. Blandano, c. 487-c. $578 \mathrm{AD}$ ) and his brother monks landing on the back 
of a whale was described in the Navigatio Sancti Brendani Abbatis (Selmer 1989). Similar tales were told in the Thousand and One Nights and in the medieval European and Arabic romances of the life of Alexander as reported by McIntosh (2000). The tale of St. Brendan seems to be somehow linked to the episode of Jonah and the great fish of Biblical tradition (Packer 2001: Jonah 2:1). Though it is often called a whale today, the Hebrew refers to no species in particular. Aristotle (Historia animalium; Louis 1964: Book I, part. 5) had already stated that whales and dolphins belonged to the category of mammals, but no such distinction was ordinarily made in antiquity and the Middle Ages. As noted by Pinto (2012), there is an interesting Persian manuscript still conserved in the Österreichischen Nationalbibliothek (Cod. Mixt. 344) of Vienna, which contains an image of a fish with Jonah emerging from it, located in the Persian Gulf/Indian Ocean. This fish resembles the big fish of the St. Brendan motif on the Pîrî Reis map. The episode of St. Brendan and the whale was often illustrated in medieval bestiaries and manuscripts (e.g., British Library, Harley MS 4751, folio 69r), in mappae mundi (e.g., Martim Behaim globe, see Van Duzer 2013), and in portolan charts of the $15^{\text {th }}$ century, such as the chart made by Mecia de Viladestes in 1413, but it does not appear on Portuguese maps until the middle of the $16^{\text {th }}$ century (see the map collection of Cortesão \& Teixiera Mota 1960), as already noted by Pîrî Reis himself. Van Duzer (2013) noted that "the Pîrî Reis map provides valuable evidence that there was a medieval European cartographic tradition of illustrating the whale episode from the story of St. Brendan". The depiction of the whale is upside-down, probably, as stated by McIntosh (2000), because medieval mappaemundi were sometimes oriented with the south at the top, as was the convention in Arabian maps (see Rizzitano 1994).

\section{AFrICA}

The portion of the map showing Africa is particularly accurate and reflects the fairly detailed grasp Europeans had acquired of this part of the Atlantic by 1513 (Soucek 2013). The interior of the map is filled with characteristic features of the continent. Two animals are associated with this part of the map: an elephant and an ostrich, Struthio camelus Linnaeus, 1758. Although the African proboscidean ought to be Loxodonta africana (Blumenbach, 1797), the representation appears to portray an animal of the Asian species, Elephas maximus Linnaeus, 1758 , since its back is convex and its ears are smaller than those of the African species. Asiatic elephants had been known in Europe since ancient times, perhaps from the works of Ctesias of Cnidus ( $5^{\text {th }}$ century BC) and/or from the conquest of western Asia by Alexander the Great (Fox 1973; Scullard 1974). They were more commonly used for military and public purposes and frequently imported to the Western world. At the beginning of the $16^{\text {th }}$ century, there is evidence of the use and importation of Asiatic elephants in Europe (for example, the famous white Indian elephant called Hanno, sent by King Manuel I of Portugal to Pope Leo X at his coronation in 1514, see Bedini 1997), whereas

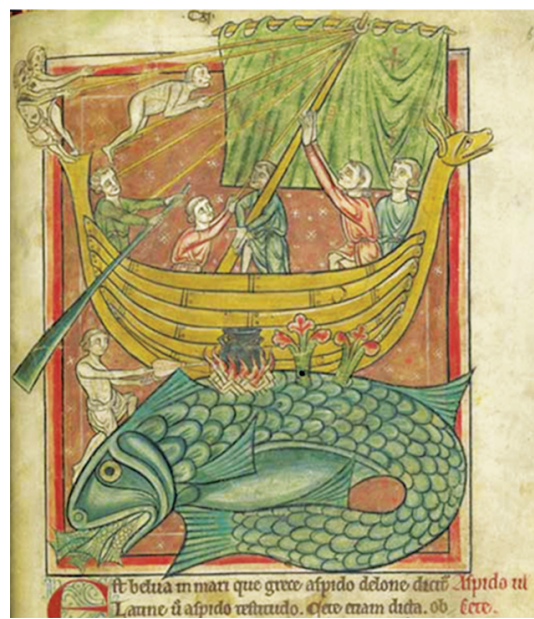

FIG. 2. - A Medieval drawing of a whale. Sailors mistake the whale for an island (Source: British Library, Harley MS 4751, Folio 69r).

the African proboscideans appear to be rarer, despite ivory trade having been a very common practice in Western Africa since the $15^{\text {th }}$-century Portuguese explorations (see Zurara 1937). A case of African elephant importation was that of a specimen brought to Whitsand on the English coast in November 1254 as a gift from the King of France, Louis IX, to Henry III of England. Asiatic elephants were a common subject on maps and mappaemundi both in Europe and the Near East. Two examples of this are the Byzantine Creation of animals, where many zoological species including an Indian elephant are illustrated in a mappamundi of the $12^{\text {th-century }}$ Seraglio Octateuch, fol 32v, (Anonymous 12th century), and the Catalan Atlas of 1375 (Anonymous 1375). After Pîrî Reis these Asiatic proboscideans continued to be featured on European maps until the end of the $16^{\text {th }}$ century (e.g., the maps of Diogo Ribeiro 1529).

Regarding the ostrich, five subspecies of this giant nonvolant bird are ordinarily recognised as occurring in Africa: the nominate subspecies, the North African ostrich or red-necked ostrich, Struthio camelus camelus Linnaeus, 1758, the Somali ostrich, Struthio camelus molybdophanes Reichenow, 1883, the Masai ostrich, Struthio camelus massaicus Neumann, 1898, the southern ostrich, Struthio camelus australis Rothschild, 1919, and the Arabian ostrich, Struthio camelus syriacus Rothschild, 1919, the only subspecies found outside Africa. The model for the Pîrî Reis birds, quite skilfully depicted, may have been an adult female (perhaps S. c. camelus), which is characterised by a less bright colouration than the male of the species. It is, however, not easy to identify the source of the Pîrî Reis image due to the fact that ostriches have been frequently portrayed in bestiaries and books of animals since antiquity. Ostriches have indeed inspired different cultures and civilizations from at least as far back as the year 20000 BC (see Takai 1974; Borzatti von Loewenstern et al. 1993). Representations of ostriches can be found in Roman mosaics and in European bestiaries (see Bartholomeus Anglicus c. 1413) and 13th-century Arabic books of animals (see Contadini 2011). Ostriches are 
also present on later maps by Diogo Ribeiro (Ribeiro 1529) and on another also by him dating to 1532 (Ribeiro 1532).

\section{ATLANTIC AND CARIBBEAN ISLANDS}

According to McIntosh (2000), there are eleven Atlantic islands characterised by the occurrence of birds on the Pîrî Reis map. These animals are shown perched on these territories, some of them recognisable as "Istonasia, Trizpose, Triz Matos, Elcerize Izle despanhya, Undiziverjine and Antilia" (McIntosh 2000). Both Kahle (1933) and McIntosh (2000) identified them as parrots. We can assume that these birds were well known to Pîrî Reis, since they are represented with almost scientific precision. Before offering our zoological interpretation of the parrots, we will first list the islands on which these birds were shown on the map.

Depicted on one of the two islands between Africa and South America is a black and white parrot with a red beak. This is the legendary island of Antilia that was often illustrated on

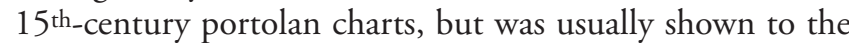
west of Europe, not to the west of Africa as on the Pîrî Reis map. The inscription referring to the island of Antilia reads:

\section{"[...] and this island they call the island of Antilia. There} are many wild beasts [i.e. monsters] and parrots and much logwood. It is not inhabited" (McIntosh 2000).

Another parrot shown on the map is associated with a group of eleven islands northeast of Puerto Rico and is accompanied by this inscription:

\section{"These small islands are called 'undizi vergini' [that is to say the eleven virgins]" (McIntosh 2000).}

These are identified with the Virgin Islands, named after the popular legend of the eleven thousand virgins of St. Ursula (Kalhe 1933). Actually, there are two groups of Virgin Islands on the Pîrî Reis map (McIntosh 2010), and the parrot stands on the "duplicated" ones that are drawn further to the north, east of Puerto Rico (see also Kalhe 1933 on this point). A third parrot is found on an island which the Turkish admiral calls Triz Matos. There are several theories regarding its identification. One of the most plausible might be that the name derives from "tres matos", meaning in Spanish "Three Mastic Trees", and referring to a commercial product the resin of which was used for medicine, and which Columbus found on his first voyage (see Perikos 1993; McIntosh 2000). This string of islands southeast of Puerto Rico can be identified as the Lesser Antilles, the islands that Columbus discovered on his second voyage. On four islands surrounding the Lesser Antilles, four more parrots of different colours are depicted, one with a very distinct white head and others with black and green-black bodies. Another parrot is shown on the southeast corner of a big island in the centre of the Caribbean Sea: this is Hispaniola, modern-day Haiti/Santo Domingo Republic. The shape and orientation of Hispaniola on the Pîrî Reis map is strikingly similar to that of the island of Cipango (Japan), as illustrated on the $15^{\text {th-century geographical }}$ maps. It also recalls the shape of Antilia as shown in the 1492 globe of Martin Behaim (Behaim 1492), as well as other later maps (La Roncière \& Mollat du Jourdin 1984). Cipango was the name given by Marco Polo to the Japanese archipelago and it was one of the original destinations of Columbus' first voyage. In fact, when Columbus discovered Hispaniola, he believed it to be Cipango (cf. Dunn \& Kelley 1989), the major axis of which he assumed to run north-south (see the Martellus world map of $c$. 1498, among others, McIntosh 2000). In addition to all these islands, two other insular territories located in the extreme northwest portion of the map are characterised by the depiction of one parrot each.

In conclusion, with the exception of Hispaniola and the Virgin Islands (the duplicated ones), it seems that none of these islands which are decorated with parrots actually exist, and their conventional shapes suggest that they are the products of fantasy (Kahle 1933). Kahle (1933) assumed that all the islands with parrots originated from the map which Columbus used on his first voyage, regarding which he communicated with Martin Alonso Pinzon on September 25, 1492. The islands that Columbus himself discovered would have been shown on this earlier map, which was modified in some aspects, as in the case of Cipango being altered to represent Hispaniola. Kahle (1933) argued that apparently, in order to prevent the confusion between the islands originally on the map and those that Columbus had actually discovered, parrots were used to distinguish the former. This theory was contested by McIntosh (2000) because Pîrî Reis also put parrots in other regions that actually existed. Moreover, Pîrî Reis also showed the same kinds of parrots on a second world map of 1528 (Reis 1528). Of this second map, only Greenland, a part of North America, Cuba, the Dominican Republic/Haiti, Jamaica and parts of Central America still survive as part of the map of the world.

As already observed, a closer examination of these birds reveals them to be parrots, parakeets and/or Aras, but they do not appear to correspond to any species known to be living today. What could they be? They may represent some kind of bird from the order Psittaciformes, and the family Psittacidae sensu lato. Three inscriptions appear on the part of the Pîrî Reis map showing the mainland of Central America, which has, however, been identified as Cuba by McIntosh (2000). The last inscription is of particular interest:

"This region is known as the province of Antilia. It is in the west. They say that there are four kinds of parrots: white, red, green and black. The people eat the flesh of parrots and their headdress is made entirely of parrots' wool [i.e. feathers]..." (Afetinan 1987).

Pîrî Reis also mentioned parrots in his Bahriye, when referring to the Spanish ships that they captured:

"In the enemy ships which we captured in the Mediterranean, we found a headdress made of these parrot feathers" (Afetinan 1987).

It is quite difficult to identify these parrots at the species level, even when consulting the legenda of the Pîrî Reis map. One of the reasons for this difficulty is that as many as 50 to 
60 endemic species of psittacids would have occupied the West Indies before human activity had a major impact, as compared to the 12 species (three of Aratinga and nine of Amazona) that survive today (Williams \& Steadman 2001). Some of these losses have clearly occurred during recent historic times, as in the case of Ara tricolor Bechstein, 1811, in Cuba and the Isla de Pinos. The Cuban red macaw is not the only extinct Caribbean macaw on record. Several additional species from a number of different West Indian islands - including Guadeloupe, Jamaica, Dominica, Hispaniola, and Martinique - have also been described and named (Shuker 2014). Yet, whereas the Cuban species is physically represented in various museums by a number of preserved specimens, the others are known only from eyewitness descriptions (in addition to several paintings based solely on such accounts rather than directly on living specimens). In the West Indies such losses have involved all three indigenous genera, Ara, Aratinga, and Amazona (Williams \& Steadman 2001).

One of the parrots most frequently found on the Pîrî Reis map has a white head and may refer to one or more subspecies of Amazona leucocephala Linnaeus, 1758, a bird endemic to the West Indies. This parrot became extinct on most of the islands as a consequence of European colonisation and probably largely due to its importation to Europe. An example of such importation is shown in the painting Portrait of Paolina Adorno Brignole-Sale (1627) by Anthony van Dyck (Museum of Palazzo Rosso, Genoa) (Fig. 3). The portrait appears to confirm Pîrî Reis' text which reported the presence of black parrots, although its identification at subspecies level is still impossible at present. Another parrot portrayed in a 17th century painting that resembles one of the Pîrî Reis birds is found in Bartholomeus van Bassen's famous painting Renaissance Interior with Banqueters (1618-1620) (Fig. 3). Here, the parrot appears similar to the birds drawn on two fantastic islands north of Cipango and also on the world map of 1528 . Some parrot species from the West Indies have indeed been described in other works, but there is not enough evidence to be conclusive. Several prehistoric and historic parrot varieties are, however, now known to have existed in the region. Originally associated with Eastern Asia and Africa, parrots became the symbol of America after the early voyages of Columbus. On Sunday 12 October 1492, when he landed in the Bahamas, Columbus wrote: "Parrot flocks are so numerous that they obscure the sun" (Navarrete 1840). According to Mobley (2009), Columbus brought back a pair of $A$. leucocephala as a gift for Queen Isabella of Spain in 1494. References to parrots are abundant in all the subsequent texts of the explorers of the New World. Parrots were very sought-after animals among Renaissance nobles and were massively imported from both Central and South America. These birds became a sort of intermediary between the two worlds and were the first American animals to circulate in Europe as representatives of an alien reality (see Pieper 2006; Gschwend 2009). The association of parrots with the New World is particularly evident in paintings and in several geographical maps of the early $16^{\text {th }}$ century, such as those of Cantino (Anonymous 1502) and/or Waldseemuller $(1507,1516)$.

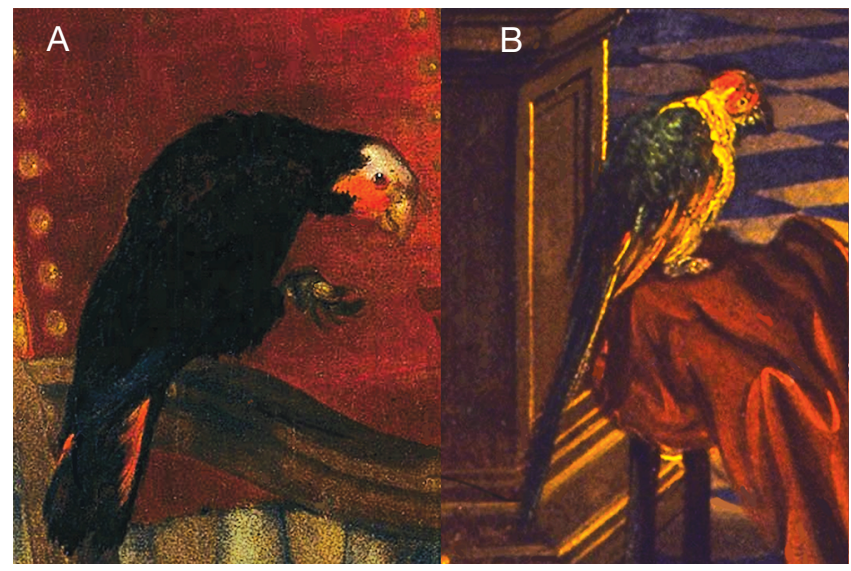

FIG. 3. - A, Detail with a parrot of Portrait of Paolina Adorno Brignole-Sale (1627), Anthony van Dyck (Museum of Palazzo Rosso, Genoa); B, Detail with a parrot from the painting Renaissance Interior With Banqueters (c. 1618-1620), Bartholomeus van Bassen's (Source: Google Art Project).

\section{SOUTH AMERICA}

The representation of South America and the description of its toponyms in the Pîrî Reis map are typical of an early $16^{\text {th }}$ century manuscript map and are based on Portuguese sources (probably dated after 1502, see McIntosh 2000); however this chart is the first to depict fantastic South American animals, particularly in Brazil. In a part of the map referring to South America, Pîrî Reis added a legend:

"In the mountains of this territory were creatures like this [dog-head man and a baboon-like monkeys] and human beings came out on the seacoast. The gold mines are endless" (Kalhe 1933).

"These monsters [headless] are seven spans long. The space between their eyes is one span, but they are harmless souls" (Afetinan 1987).

These fantastic creatures had already occasionally been depicted in medieval mappaemundi and many of them were associated with either Africa or Asia, such as the headless men and the yale respectively. For instance creatures such as the cynocephali (dog-heads), "headless" men or blemmyes (acephali), dragons, unicorns and similar 12th-century monsters are present in the $14^{\text {th }}$-century mappamundi of Ranulph Higden (1363) among others (see Van Duzer 2010). De La Cosa's map (1500) also shows a blemmye and a dog-faced man in the Far East, in the approximate location of China. After Pîrî Reis they are also found on the chart of Guillaume Le Testu (1555) and associated with the New World on the map of Sebastian Cabot (1544) and that of Guiana by de Bry (1599) (see also Mason 1994, for a discussion on the classical monstrous races to the New World). In the prologue to his most important cartographic work, the Kitab-I Bahriye, Pîrî Reis described some of these same fabulous beings and said they lived on islands in the Chinese sea (McIntosh 2000). These monsters had been described for the first time as asso- 


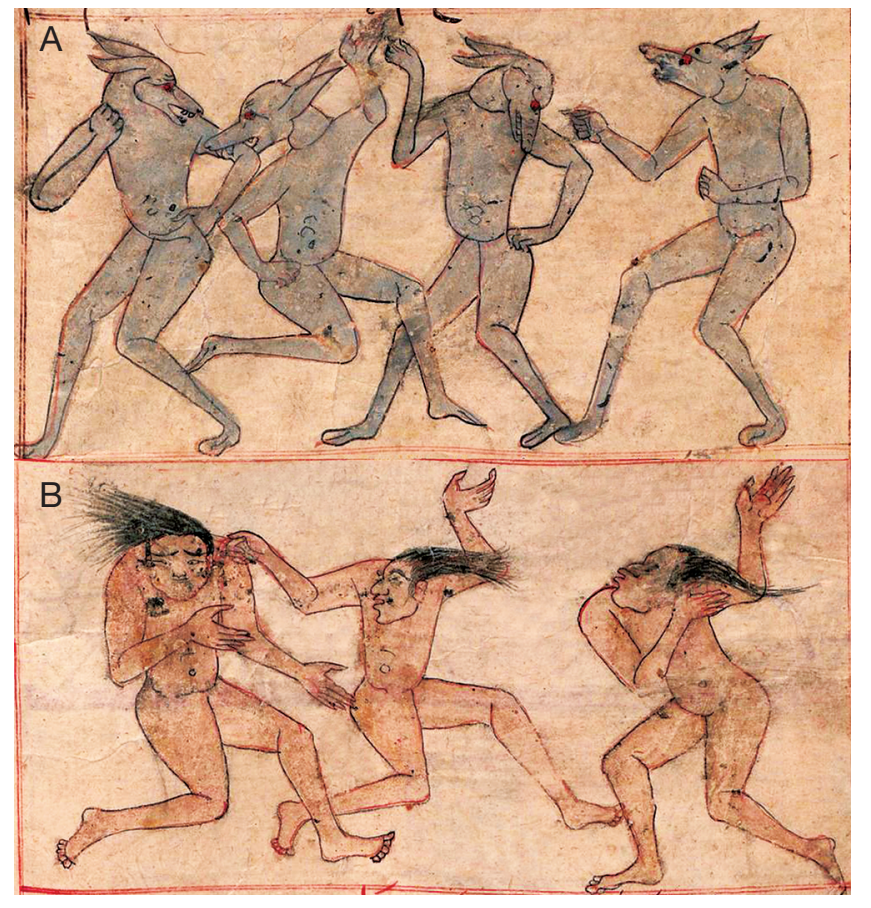

FIG. 4. - A, Dog-headed creatures; B, less-headed creatures. From the Marvels of Things Created by al-Qazwinī (1283). This is the oldest known textual witness to the original work. (Source: Library of Congress, World Digital Library).

ciated with the western lands of Libya by Herodotus in The Histories (Godley 1921: IV, 191-192):

"In that western part of the Libya there are [...] the horned asses, the dog-headed men and the headless that have their eyes in their breasts, as the Libyans say, and the wild men and wild women, besides many other ferocious beasts not fabulous".

Other classical and medieval authors (e.g., Indika, Ctesias of Cnidus $5^{\text {th }}$ century BC [Nichols 2008], the Historia Naturalis of Pliny the Elder 23-79 AD [Rackham 1983], the Collectanea rerum memorabilium of Solinus $3^{\text {rd }}$ century [Mommsen 1895], the Travels of John de Mandeville 1300 [Seymour 1967], and the Physiologus [Zambon 1975]) also reported these creatures. The dog-headed men are among the borderline creatures, very close to the human species, which both the Islamic and European traditions locate at the edges of the known world or beyond it.McIntosh (2000) observed that Pîrî Reis' immediate source might have been one of the Arab books of animals or encyclopaedic works such as the 'Ajā'ib al-makhlūqāt wa-gharā'ib al-mawjūdāt (Marvels of Things Created and Miraculous Aspects of Things Existing) of al-Qazwīnī, Zakarīyā Ibn Muhammad, (Qazwīnī 1283) or the Nuzhatu-1-Qulib by Hamdullah-Al-Mustauf-Al-Qazwini (14th century, see Hamdullah-Al-Mustaufi-Al-Qazwini, 1928). The first treatise is among the best-known texts of the Islamic world. The genre of Aja'ib al-makhluqat (The Wonders of Creation), of which al-Qazwini's work is the most famous example, includes texts in Arabic and Persian that describe the marvels of the heavens and the earth, including animals and fantastic creatures. Numerous manuscripts of al-Qazwini's work have survived and the Persian, Turkish or Indian translations are frequently illustrated. Sources such as one of the copies of the work of al-Qazwinin (see Qazwīnī 1283) in which zoomorphic figures with their faces on their chests (headless), cynocephali and other humanoid creatures were said to inhabit a remote island near the edge of the known world (see for instance Fig. 4), may have provided the inspiration for Pîrî Reis' work. Other illustrated 13th-century Arabic books on animals in the Ibn Bakhtīshū tradition (see Contadini 2011) could also have been sources for Pîrî Reis' map.

On the Pîrî Reis chart, two primates are represented in association with these mythical creatures. One of them is shown near to an acephalous man and is holding a piece of fruit in its hand, whereas the other is "dancing" with a cynocephalus. Pinto (2012) interpreted the first association (the headless man and the monkey with the fruit) as a citation from a map in a late $15^{\text {th-early }} 16^{\text {th }}$-century manuscript (the Bağdat 334 al-Istakhri Kitab al-Masalik wa al-Mamalik genre manuscript conserved in the library of Topkapi Palace), where there is a scene of a man and a monkey on top of some rocks. Pinto (2012) observed that: "The parallels between this image and the image of the monkey and the Blemmye in the 1513 Piri Reis map are immediately apparent. Although the depiction is different there is a distinct resemblance." We agree with Pinto (2012) about the fact that Islamic maps and manuscripts could have been the source of inspiration for Pîrî Reis, but Pinto's specific interpretation is not wholly convincing, partly because it does not explain the presence of other zoomorphic figures in the shape of monkeys. On the other hand, Casale (2010) states that knowledge of contemporary Arab charts was not widespread in the Ottoman world until the second half of the $16^{\text {th }}$ century. Indeed, Pîrî Reis could have acquired another original source of information about New World monkeys directly from the Europeans who often described these lands as full of monkeys. This first monkey is baboon-like and it is possible to infer that its portrait was made based on African or Asiatic primate referents. The other monkey has a long tail and could vaguely recall the morphology of an African guenon or certain Neotropical monkeys, such as capuchin monkeys of the genera Sapajus or Cebus spp. These kinds of primates were described by the first explorers and imported in large numbers to Europe from the early 1500 s (see Veracini 2011). The comparison and identification of New World primates with already known Asiatic or African species of monkeys is present in some of the first chronicles about New World exploration from the $16^{\text {th }}$ century, such as those of Columbus and Vespucci (Veracini 2011; Masseti \& Veracini 2014). When Columbus reached the Caribbean coasts in 1492, he thought he had arrived on the east coast of Asia, and all his descriptions of animals and plants were influenced by this idea. In his third transatlantic voyage in 1498 when he landed on the Paria Peninsula (in what is now Venezuela), Columbus referred to his first encounter 
with a local primate which he called by the Spanish name gato paul, which is the equivalent to the English "sea cat", the name used for monkeys with tails.

"[...] and I sent boats ashore, and they found that people there had left, and they found the whole mountain covered with sea-cats (gatos paules in the Spanish text, i.e. monkeys)" (Navarrete 1840: 399).

We know that Columbus' source for the name he gave to monkeys was The Travels of Marco Polo (see Urbani 2004; Asua \& French 2005), so that he identified the Neotropical monkeys of the Caribbean with the Asian ones referred to in that source. In 1502, in a letter about his second voyage along the coast of Brazil, Amerigo Vespucci (Florence, 1454 - Seville, 1512) described how pleasant and beautiful the land he had found was; he also recorded many wild beasts, freely using the names of Old World animals. He noted that these new lands were filled with a large variety of monkeys including "baboons" (see Spila 2007). Moreover, in the other earliest maps of the New World (for example, the Lopo Homem "Atlas Miller", Lopo Homem c. 1519) depictions of other African monkeys such as the Barbary macaque Macaca sylvanus (Linnaeus, 1758) are often encountered. This fact is easily explained, since the Barbary macaque is the most frequently illustrated monkey in the iconography of antiquity, the late Middle Ages and early Modern Europe, and it was used as a stereotyped model for a generic portrayal of monkeys.

\section{The camahueto and the monocerus}

In the portion of the map that can be interpreted as the eastcentral Brazilian region, three other mammals are depicted. One of them is characterised by an outgrowth on the head that can be interpreted as a prehensile snout and artiodactyl feet. This animal might be a specimen of the genus Tapirus Brünnich, 1772 , based on other explorers' reports of it being found in that region. It is represented in a portion of South America where only the lowland tapir, Tapirus terrestris (Linnaeus, 1758) can be found today (Grubbs 2002). Considering the uniform coat colour in the depiction on the map the identification with this tapir, characterised by the occurrence of a crown rising in a humped crest between ears, gains further plausibility. However, its feet do not correspond to those of an artiodactyl, since the tapir is a perissodactyl. In reality, the depiction seems to portray a camahueto or chivato marino, a sort of water monster resembling a calf with a small horn on its forehead similar to that of a unicorn. This creature is believed to be a species of "water cattle" of the coastal areas of southern Chile and the island of Chiloé (Rajcak \& Laverdin 2012). The legends of the native peoples of these places say that these animals are born in inland rivers and when they reach adult size the camahuetos start their migration to the sea. While walking, these animals make marks on the ground with their horns, giving rise to small streams and sometimes even to rivers.

Nevertheless, it cannot be ruled out that the origin of the camahueto representation on the Pîrî Reis map may have been the Persian shädawàr, because at the time the chart

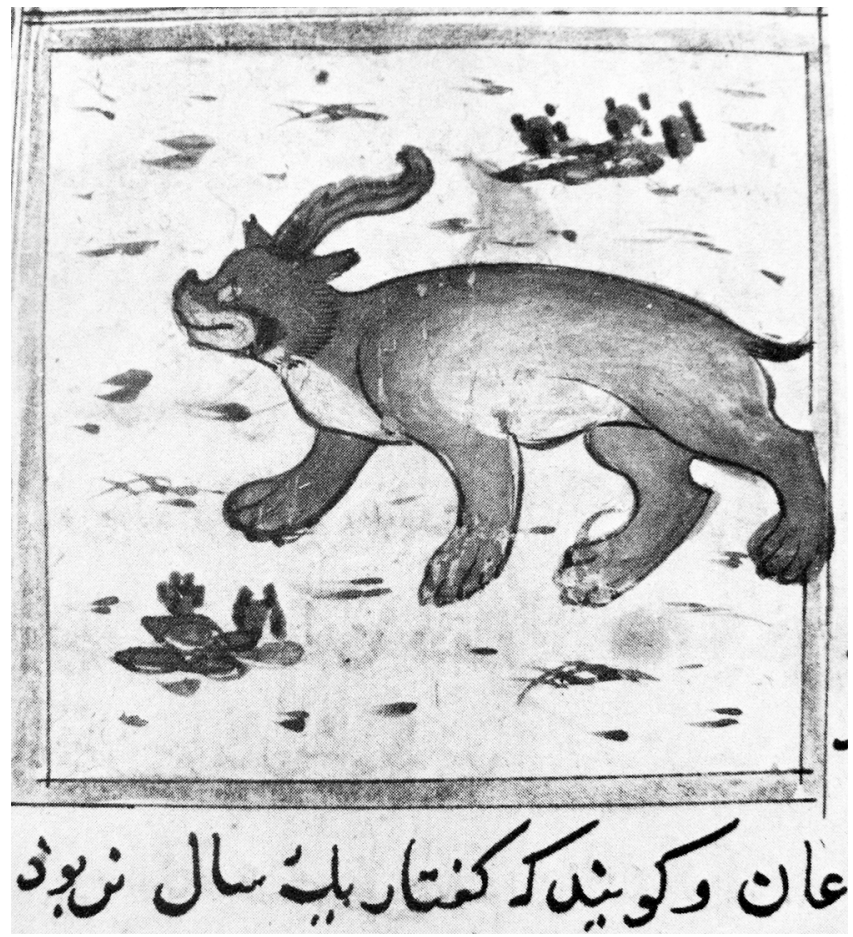

FIG. 5. - "The shādawār that makes sweet music" according to a Persian miniature. Shiraz c. 1440 (from Robinson 1980, modified).

was made Chile was still far from being discovered. In fact, Ferdinand Magellan found the passage in the strait which bears his name, at the southern tip of South America, only in 1520. The Persian shädawār is a mythical animal that makes sweet music. Although it is generally represented with branching horns, sometimes it is depicted in a different way such as that found in a Persian miniature dating to around 1440 (Robinson 1980), (see for example Fig. 5). The latter creature has been described as an ungulate unicorn that lived in Turkey and neighbouring countries (Rajcak \& Laverdin 2012), sometimes also identified with the Arabian oryx, Oryx leucoryx (Pallas, 1777) (Masseti 1980, 1988). The same zoomorphic figure on the Pîrî Reis map has also been identified with the monoceros by McIntosh (2000). This mythical creature, however, should not be confused with the unicorn and represents what the ancients called the Indian ass, actually the rhinoceros (Druce 1914). Its description, with some slight variation, is taken from Solinus:

"a great beast with a terrible bellow, the body of a horse, the feet of an elephant, a tail very like that of a stag and a horn in the middle of its forehead, which projects with an astonishing magnificence to the length of four feet, and is so sharp that anything that it strikes is easily pierced by the blow. It does not come into man's power alive, and it can be killed indeed but cannot be captured" (Druce 1914).

Pîrî Reis himself may have been referring to a monoceros when he described an island drawn in the midst of the Atlantic Ocean. He called this island Isla de Vaca or Cow Island, dubiously identified as Salvaga by McIntosh (2000). This 


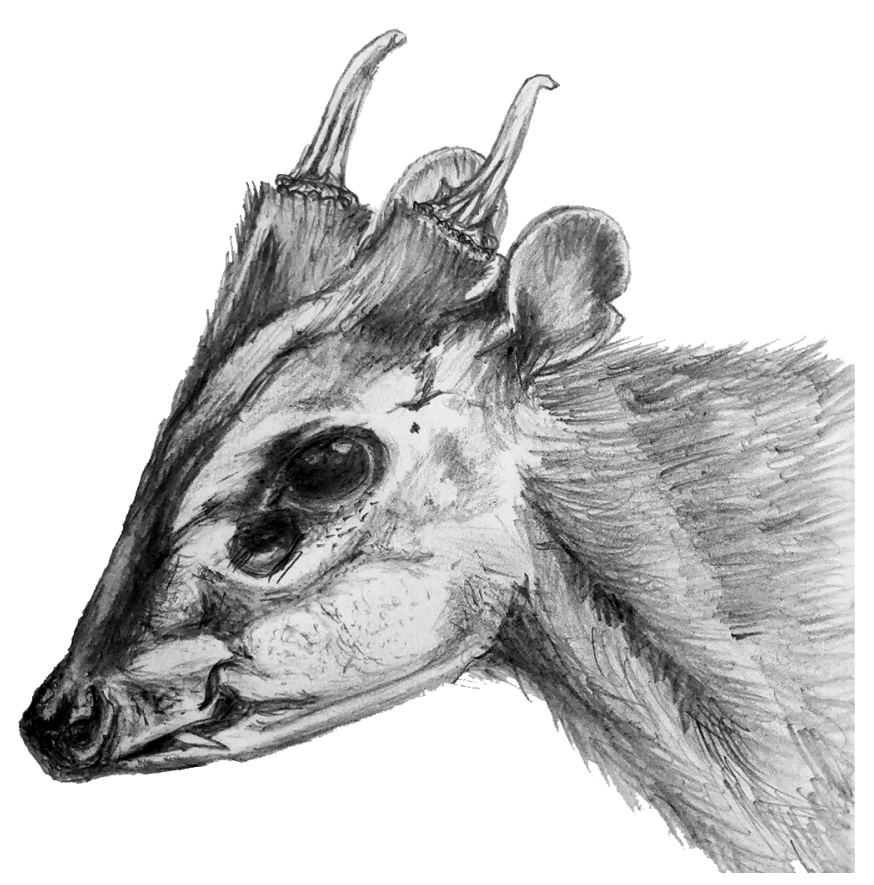

FIG. 6. - A Reeves' muntjac (Muntiacus reevesi Ogilby, 1839), a species of Middle and Far Eastern cervid of the genus Muntiacus Rafinesque, 1815 which might be the inspiration for the mythical yael. (Drawing: Cecilia Veracini)

island is another legendary territory, which was believed to be inhabited by "many oxen with one horn", as noted by Pîrî Reis.

\section{The yale}

The second creature represented in the east-central Brazilian region is another mythical animal, the famous yale (also centicore, in Latin eale) of European mythology (George 1968; Payne 1990). It resembles an oversized deer with a white coat and long curved horns (Rajcak \& Laverdin 2012). Most descriptions render it as a spotted horse-like creature, antelope or goat-like, four-legged monster. This fantastic animal was once said to thrive in North Africa, grew to the size of a horse and had a long swishing tail similar to an elephant's. It had a broad face with an upturned snout and bared protruding incisors identical to a wild boar's (Largo 2013). Its most notable feature was a pair of long horns which pointed either forwards or backwards. In fact, the yale's cranial appendices were attached by a joint that allowed them to swivel and fight off enemies from every direction. It was omnivorous, though it apparently preferred grazing and seems to have been related to the antelope family. Its main competitor was the dreaded basilisk. The two beasts were natural enemies, with a reciprocal enmity that appears to have led to them causing each other's extinction, if indeed either ever actually existed.

The name of this monster could be derived from the Hebrew yael, meaning "mountain goat", the Nubian ibex, Capra ibex nubiana Cuvier, 1825 ("The high hills are a refuge for the wild goats": Psalms, 104-108; see Tzon 1978). In view of its peculiar morphology, however, it cannot be ruled out that the source of the inspiration for the yael is a species of Middle and Far Eastern cervid of the genus Muntiacus Rafinesue, 1815 (Fig. 6). In a review of the yale's iconography, George (1968) suggested interpreting this creature as an elaboration of the morphology of the water buffalo, Bubalus bubalis (Linnaeus, 1758), on the basis of arguments which are not entirely convincing.

The third animal depicted in the east-central Brazilian region is a carnivore. Although Afetinan (1987) identified this beast with the present-day South American puma, Puma concolor Jardine, 1834, it does not look like a felid, and reveals certain characteristics possibly of the Mustelidae family. The inscription that refers to this creature is as follows:

$$
\text { "They call this beast sami" (McIntosh, 2000). }
$$

According to McIntosh (2000), this name seems completely out of context. Based on its shape and coloration, the animal looks like a representation of one of the carnivores found in the Arabic bestiaries (for example, the above-mentioned al-Qazwīnī), but its certain identification remains very difficult.

\section{Patagonia - Southern Continent}

To the South, the vast continent that closes the Atlantic is an adaptation of the Ptolemaic concept of the world, still commonly used in the first quarter of the 16 th century (Afetinan 1987; La Roncière \& Mollat du Jourdin 1984). This area, south of the Plata River, extends to the east and can be identified with the territory of Patagonia. Eight years later in the Babriye, Pîrî Reis affirmed that "further south there is no land but sea", indicating that he was following later discoveries with careful attention (Afetinan 1987). The claim that this lower part of the map portrays the Princess Martha Coast of Queen Maud Land in Antarctica and the Palmer Peninsula made by Hancock (1995), as noted before, does not seem consistent according to McIntosh (2000). Indeed, he made a complete review of all the claims and fantastic theories about this part of the Pîrî Reis map, disputing the fact that Pîrî Reis' sources in drawing the map came from an alleged highly advanced pre-Columbian civilization or even alien astronauts. The inscription by Pîrî Reis in the part of the map that seems to correspond to Patagonia is:

"At this place the Portuguese infidels report that when night and day are short there are two hours when they are long there are 22 hours. But by day it is very hot and by night much dew falls" (Kalhe 1933).

Three animals are represented in this portion of the map. The images of two of them are in a bad state of conservation, but it is possible to deduce that one refers to a creature similar to the monoceros, while the other can be identified as the already mentioned Persian shädawār in its more classical representation, characterised by branching horns. The following inscription is next to the image of this quadruped with six horns: 


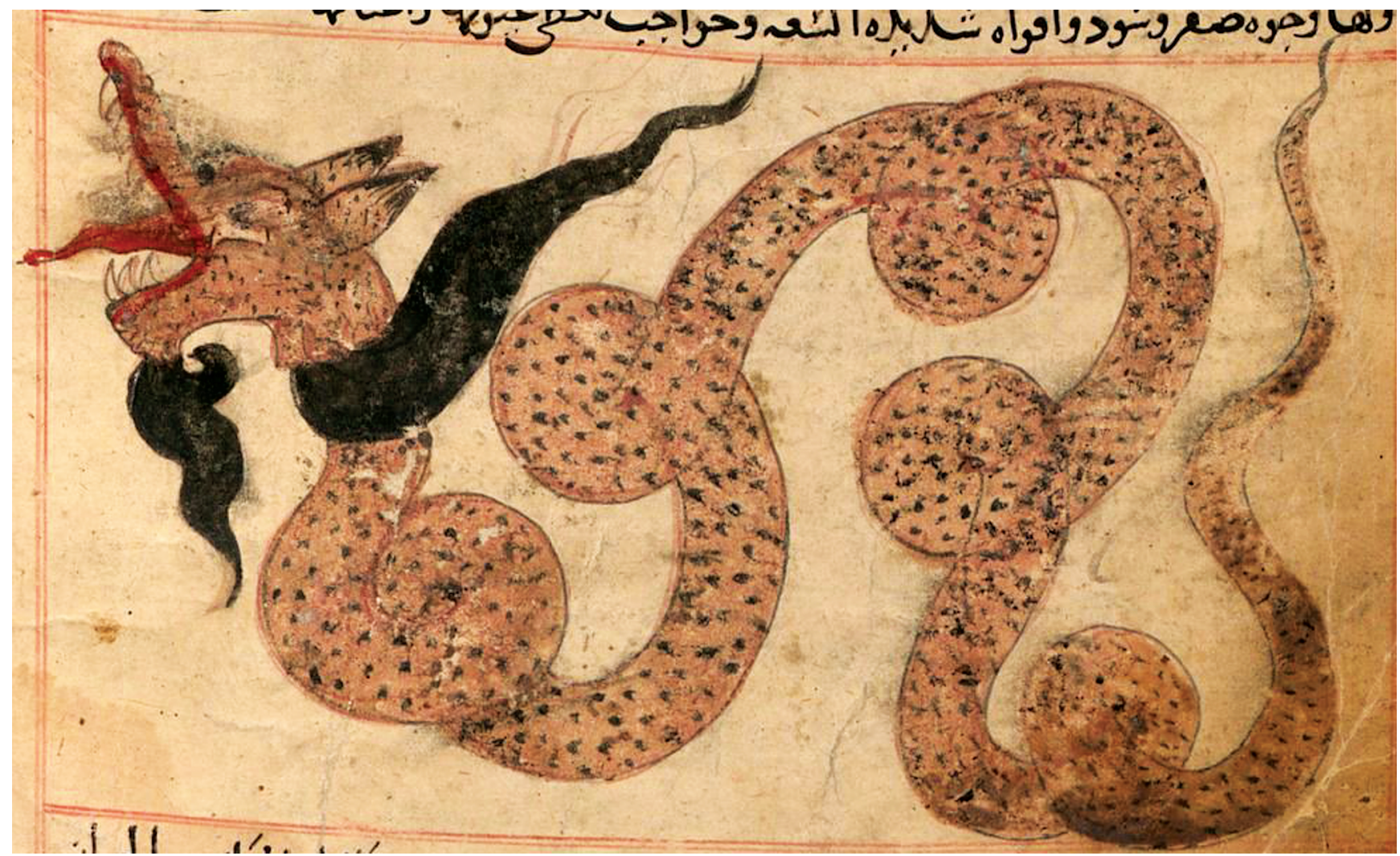

Fla. 7. - A dragon from the Marvels of Things Created by al-Qazwīnī (1283). (Source: Library of Congress, World Digital Library).

"And in this territory it seems that there are white-haired wild beasts in this shape and also six-horned oxen. The Portuguese infidels have written it on their maps" (McIntosh 2000).

The third animal has the semblance of a giant terrestrial snake. Its depiction recalls the medieval representation of fabulous drakes (especially in the face) or the mythical Tunnin, a creature like a serpent or dragon (whether land-dwelling or sea-dwelling) of Biblical origin (see for instance: Genesis 1:21 or Psalm 74:13). In the "Marvels of Things Created" of al-Qazwinī there are many illustrations of dragon or giant snakes resembling the one reproduced on the Pîrî Reis map (Fig. 7). However, Pîrî Reis could have been familiar with reports of travellers describing the big snakes (boas and/or anacondas) of the New World, and this might have been his way of representing the Neotropical reptiles. The inscription on the map next to the image of the snake is as follows:

"In this country there is no trace of cultivation. All is desolate, and big snakes are said to be there. For this reason the Portuguese infidels are said not to have disembarked on the shore and even many. . . [illegible] are said to be there" (Kalhe 1933).

Several maps of the $16^{\text {th }}$ century, such as those by Gastaldi in 1561 and Mercator in 1569, have an inscription similar to this one on that part of the Southern Continent to the south of the Atlantic Ocean, stating that the land was seen by the Portuguese but that they did not stop there (McIntosh 2000). It has been plausibly suggested that this later inscription, although located on the Southern Continent, refers to the Tristan da Cunha Islands that were discovered by the Portuguese admiral Tristão da Cunha on his way to the Cape of Good Hope in 1506. The additional information about snakes probably refers to Brazil. Presumably, Pîrî Reis could have copied this inscription from one of the Portuguese maps he used. In another note on the map, he quotes Columbus speaking about the snakes he encountered on one of the Caribbean islands:

"They said Columbus also saw an island, to which they went; they saw that on this island were large snakes. These snakes they avoided, and [they] went to another island and dropped anchor" (Kahle 1933).

Boas and anacondas, from the non-venomous Boidae family, are the largest snakes found from Central to South America (McDiarmid et al. 1999). With its many subspecies, Boa constrictor Linnaeus, 1758, is found from Mexico to northern Argentina and in the Lesser Antilles, flourishing in a wide variety of environmental conditions from tropical rainforests to arid lands (Stidworthy 1974). The southern distribution of the anaconda, Eunectes notaeus Cope, 1862, encompasses the Argentinean provinces of Corrientes, Chaco, Entre Rios, 
Formosa, Misiones and Santa Fe. The absence of representative examples of this herpetological taxonomic group in Patagonia raises significant questions, including that of whether Pîrî Reis could have utilised some of the above-mentioned sources to evoke this snake in such a southerly geographic region where the species could in fact never have been reported.

\section{CONCLUDING REMARKS}

Like the majority of the maps of the first two decades of the $16^{\text {th }}$ century, the Pîrî Reis chart is a product of the attempt to combine the reported geography of the new lands with the differing conceptions of the Old World envisaged by Ptolemy, Marco Polo, Toscanelli, Martellus, Columbus and the Portuguese navigators. The map of Pîrî Reis displays all the elements of the portolan charts, such as cities, rulers and other persons worthy of note, as well as animals, rivers, mountains and other types of geographical and cultural features. With the adaptation of the portolan charts to the oceans and newly-discovered or explored territories, brief texts were added to tell the story of a voyage or of the quaint creatures or plants or other novelties found there. Pîrî Reis' world map eloquently displays most of these elements. In drawing the map, the Turkish admiral followed rigorous scientific principles as shown by Afetinan (1987), but did not fail to fill it with the fantastic creatures associated with lands located on the margins of the unknown worlds.

During the analysis of the zoomorphic images of the Pîrî Reis map we observed two different patterns of representation of the animals: one more realistic and another more fabulous. In the portion of the map showing Africa, which is fairly accurate in its geographical contents, the animals are depicted in a fairly naturalistic way, not unlike those encountered on other previous maps. The late medieval iconography often shows animals such as ostriches and elephants associated with Africa. In this sense Pîrî Reis merely illustrates what was taken for granted in contemporary knowledge about the African fauna. Nevertheless it is impossible to know whether the admiral could have had access to Portuguese chronicles or to recent information about Africa that mentioned the new animal species which the Portuguese had begun to encounter from the second half of the $15^{\text {th }}$ century (see Monod et al. 1951; Veracini \& Casanova in press). It is well known that many of these chronicles were regarded as state secrets in Portugal and hence not accessible (Da Costa 2009). The fabulous creatures that fill the New World lands on the map had been previously associated with either Asia or Africa on late medieval maps or mappaemundi, but the Pîrî Reis map was the first (and one of the few) to depict these legendary beasts in the New World. These mythical creatures would eventually disappear with the arrival in Europe of new and more realistic descriptions of South American animals in the decades after Pîrî Reis (see Asua \& French 2005). Many of the sources that Pîrî Reis used to describe the American animals can be traced to bestiaries or Arabic books of animals, combined with the little first-hand information to which he had access (for instance, Portuguese portolan charts, the chart of Columbus and so on) that described the reality encountered in the New World in a very succinct and sometimes imprecise manner. Indeed, to draw South America, Pîrî Reis used the most recent Portuguese maps and added the remarks of Amerigo Vespucci, Pinzon and Joei de Solis (Afetinan 1987). However, as observed by Soucek (1992, 2013), Pîrî Reis was not very familiar with neo-Latin idioms (as shown by the approximation of certain translations) and thus he might have left out many of the new sources in his references. Due to language difficulties, he may have had limited access to the Spanish, Portuguese and Italian literature about America that began to circulate in Europe in the early 1500 s, and possibly for this reason simply referred to the mythological or well-known creatures of bestiary origin.

However, although many of Pîrî Reis' American animals fall into this pattern, the parrots may come from a different type of source. We can assume that these drawings originated from the lost map of Columbus or another document which had come into Pîrî Reis' possession, since they appear unrelated to any previous source. As shown in the reconstruction of Central America and the Caribbean islands (though he had at his disposal the newer Portuguese portolan charts), Pîrî Reis did not forego the use of the only chart drawn by Columbus that was in his possession, thus committing many mistakes that he did not make in other parts of South America or Africa. Pîrî Reis was indeed greatly fascinated by Columbus, as shown by the fact that both on the map and in the Kitab-I Bahriye, the Turkish admiral included a long digression about how the famous Genoese explorer had prepared and carried out his voyage (Soucek 2013). If the parrots drawn on the Pîrî Reis map, and analysed here for the first time from a zoological point of view, originated from Columbus' chart, their images could be among the very scarce evidence of these birds before the various extinctions occurred following the contact with Europeans.

\section{Acknowledgements}

We should like to express our appreciation and gratitude to: the two anonymous referees for their useful comments and suggestions, Giorgio Galletti, Università di Firenze, and Norma Chapman for having put at our disposal the photographic image of the Reeves' muntjac.

\section{REFERENCES}

\section{BIBLIOGRAPHY}

AfETINAN A. 1987. - Life and works of Pîrî Reis. The oldest map of America. Second edition. Turkish Historical Society, Ankara, 88 p. Asua M. DE \& French R. 2005. - A New World of Animals. Early Modern Creatures of Iberian America. Ashgate, Burlington, $257 \mathrm{p}$.

BarTholomeus Anglicus. c. 1413. - Livre des propriétés des choses. (ms. 993, Folio 159v.). Bibliothèque Municipale de Reims. http://bestiary.ca/beasts/beastgallery238.htm last consultation: 17/05/2016.

Bedini S. A. 1997. - The Pope's Elephant. Carcanet Press, Manchester, $302 \mathrm{p}$. 
BORZATTI VON LOWESTERN E., MASSETI M. \& Vianello F. 1993. On the former distribution of the ostrich (Struthio camelus syriacus Rotschild, 1919) in Southern Jordan. Studi per l'Ecologia del Quaternario 15: 75-80.

Campbell T. 1987. - The Earliest Printed Maps. British Museum Press, London, $244 \mathrm{p}$.

Casale G. 2010. - The Ottoman Age of Exploration. Oxford University Press, New-York, 304 p. http://dx.doi.org/10.1086/678820

ConTADINI A. 2011. - A World of Beasts: a Thirteenth-Century Illustrated Arabic Book on Animals (the Kitäb Na't al-Hayawän) in the Ibn Bakhtishū'Tradition. Brill, Leiden, 209 p.

Cortesão A. \& TeiXiera da Mota A. 1960. — Portugaliae Monumenta Cartographica. Coimbra University Press, Coimbra, 163 p.

DA CosTA P. F. 2009. - Secrecy, ostentation, and the illustration of exotic animals in sixteenth-century Portugal. Annals of Science 66 (1): 59-82. http://dx.doi.org/10.1080/00033790802388428

DruCE G. C. 1914. - Animals in English Wood Carving. The Third Annual Volume of the Walpole Society, 1913-1914, Oxford. http:// bestiary.ca/etexts/druce1914/druce\%20-\%20animals\%20in\%20 english $\% 20$ wood $\% 20$ carvings.pdf last consultation: 17/12/2016.

DunN O. \& Kelley J. E. 1989. - The Diario of Columbus's First Voyage to America, 1492-1493. Norman University of Oklahoma Press, Oklahoma, $491 \mathrm{p}$.

Edson E. \& Savage-Smith E. 2004. - Medieval Views of the Cosmos. Boedleian Library, University of Oxford, $128 \mathrm{p}$.

Fox L. 1973. - Alexander the Great. Penguin Book, 568 p.

GEORGE W. 1968. - The yale. Journal of the Warburg and Courtauld Institutes 31: 423-428.

Godley A. D. (ed.) 1921. - Herodotus: the Persian Wars. Volume 2: Books III-IV. Loeb Classical Library; Harvard University Press, Cambridge, London, 448 p.

GRUBBs P. 2002. — Order Perissodactyla, in WiLSON D. E. \& REeder D. A. M (eds.), Mammal Species of the World. A Taxonomic and Geographic Reference. Third edition. The John Hopkins University Press, Baltimore: 111-184.

GsChWEnd A. J. 2009. — The Portuguese Quest for Exotic Animals, in Hallett J. (ed.), Triumphal Procession with Giraffes. Centro Historia Além-Mar, Lisbon: 32-42.

Hancock A. 1995. - Fingerprints of the Gods. Three Rivers Press, New York, 592 p.

Hassig D. 2013. - The Mark of the Beast: the Medieval Bestiary in Art, Life and Literature. Routeledge, New York, London, $230 \mathrm{p}$.

KaHLE P. 1933. - A lost map of Columbus. Geographical Review 23 (4): 621-638.

Largo M. 2013. - The Big, Bad Book of Beasts. William Morrow, New York, $464 \mathrm{p}$.

La Roncière M. DE \& Mollat du Jourdin M. 1984. — Les Portulans, cartes marines du XIIIe au XVIIe siècle. Nathan, Paris, 295 p.

LouIS P. (ed.) 1964. - Aristote, histoire des animaux. Tome I, Livres $I-I V$. Les Belles Lettres, Paris, 184 p.

MASON P. 1994. - Classical ethnography and its influence on the European perception of the peoples of the new world, in HAASE W. \& MeYer R. (eds), The Classical Tradition and the Americas, European Images of the Americas and the Classical Tradition 1 (1): 135-172.

MASSETI M. 1980. - Nel paese dei "borui" e dei "dittei”. Le Lingue del Mondo 3 (65): 217-220.

MASSETI M. 1988. — La fauna del norte de Africa en el V milenio a. J.C. Boletin del Instituto de Estudios Almereinses, "Homenaje a Antonio Cano Ge": 149-162.

Masseti M. \& Veracini C. 2014. — Early European knowledge and trade of Neotropical mammals: a review of literary sources between 1492 and the first two decades of the 16 $6^{\text {th }}$ Century. Proceeding of the First Zooarchaeology Conference in Portugal, British Archaeological Reports: 129-138.

Mc Diarmid R. W., Campbell J. A. \& Touré T. 1999. - Snake Species of the World: a Taxonomic and Geographic Reference. Vol. 1. Herpetologists' League, Washington, xi + 511 p.
McIntosh G. C. 2000. - The Pîrî Reis map of 1513. University of Georgia Press, Athens, 230 p.

Mobley J. A. (ed.) 2009. — Birds of the world. Marshall Cavendish Corporation, New York, 482 p.

Mommsen T. 1895. - C. Iulii Solini, Collectanea Rerum Memorabilium. Weidmann, Berlin, 396 p. https://archive.org/details/ collectanearerum00soliuoft last consultation: 25/05/2016.

Monod T. H., Mota A. T. \& Maunt R. 1951. - Description de la Côte Occidentale d'Afrique (Sénégal au Cap du Monte, Archipels) Par Valentim Fernandes 1506-1510. Memórias do Centro de Estudos da Guiné Portuguesa, Bissau, 110 p.

NAVARRETE M. F. DE 1840. - Narrazione dei Quattro Viaggi intrapresi da Cristoforo Colombo per la scoperta del nuovo continente dal 1492 al 1504. Giachetti, Prato, 551 p.

Nichols A. 2008. - The Complete Fragments of Ctesias of Cnidus: Translation and Commentary with an Introduction. PhD Dissertation, University of Florida, $252 \mathrm{p}$.

PACKer J. L. (ed.) 2001. - The Holy Bible, English Standard Version. Crossway Bibles, Wheaton, 1380 p.

PaYne A. 1990. - Medieval Beasts. The British Library, London, 96 p. Perikos J. 1993. - The Chios Gum Mastic. Graphic Arts, Athens, 95 p.

Pieper R. 2006. - Papagayos americanos, mediadores culturales entre dos mundos, in StOls E., Werner T. \& Verberckmoes J. (eds), Naturalia, Mirabilia \& Monstrosa en los Imperios Ibéricos. Presses Universitaires de Louvain, Louvain: 123-134.

PINTO K. C. 2012. - Searchin' his eyes, lookin' for traces: Piri Reis' World Map of 1513 \& its islamic iconographic connections (a reading through Bagdat 334 and Proust). Journal of Ottoman Studies 39 (1): 63-94.

QAZWĪNī AL Z. M. 1283. - 'Ajäìb al-makhlūqāt wa-gharäìb al-mawjūdāt (in Arabic; English translation: Marvels of Things Created and Miraculous Aspects of Things Existing or The Wonders of Creation). https://www.wdl.org/en/item/8962/ last consultation: 25/05/2016.

RackHAm H. (ed.) 1983. - Pliny Natural History. Harvard University Press, Cambridge; William Heinniman, London, 616 p.

RAJCAK H. \& LAVERDIN D. 2012. - Histoires naturelles des animaux imaginaires. Actes Sud Junior, Paris, 80 p.

RizziTANo U. (ed.) 1994. - Idrisi. Il Libro di Ruggiero. Il diletto di chi è appassionato per le peregrinazioni attraverso il mondo. Flaccovio Editore, Palermo, $135 \mathrm{p}$.

RoBINSON B. W. 1980. — Persian Paintings in the John Rylands Library: a Descriptive Catalogue. Sotheby Parke Bernet, London, 365 p.

SCUlLard H. H. 1974. - The Elephant in the Greek and Roman World. Thames and Hudson, Cambridge, 288 p.

Selmer C. (ed.) 1989. — "Navigatio Sancti Brendani abbatis" from Early Latin Manuscripts. Publications in Medieval Studies 16. Four Courts Press, Dublin, xlix + 132 p. [1st ed. 1959]

SeYmour M. C. 1967. — Mandeville's Travels. Clarendon, Oxford, $188 \mathrm{p}$.

SHUKER K. 2014. - Dominica's dead parrot - a perfect picture of mystery? Shukernature 23. http://karlshuker.blogspot.it/2014/02/ dominicas-dead-parrot-perfect-picture.html last consultation: 26/05/2016.

SOUCEK S. 1992. - Islamic charting in the Mediterranean, in HARLEY J. B. \&WoOdward D. (eds), The History of Cartography. Vol. II, Book I, Cartography in the traditional Islamic and South Asian societies. University of Chicago Press, Chicago, London: 263-292.

SouceK S. 2013. - Pîrî Reis. Turkish Mapmaking after Columbus. Boyut Publishing Ltd., Instanbul, 135 p.

SpILA C. 2007. - Amerigo Vespucci. Mundus novus. Città Aperta, Troina, $96 \mathrm{p}$.

STEPHENSON J. 1928. - The zoological section of the Nuzhatu-lQuliûb: a Persian Compendium of Science, 1340 A. D. Isis 11 (2): 285-315. http://www.jstor.org/stable/224423

STIDWORTHY J. 1974. - Snakes of the World. Grosset \& Dunlap, New-York, 160 p. 
TAKAI F. 1974. - Fossil vertebrate from the Doura cave site, in SuZuki H. \& TAKaI F. (eds), The Palaeolithic Site at Doura Cave in Syria. Part II. University of Tokyo Press, Tokyo: 169-181.

Tzon U. 1978. - Hai-Bar, Eilat. The National Biblical Wild Life Reserve in Israel. Palphot, Tel Aviv, 18 p.

URBANI B. 2004. - Further information on Neotropical monkeys reported in the XVI century. Neotropical Primates 12 (3): 146-147.

VAN DuZER C. A. 2010. - A Northern Refuge of the Monstrous Races: Asia on Waldseemüller's 1516 Carta Marina. The International Journal for the History of Cartography 62 (2): 221-231 http://dx.doi.org/10.1080/03085691003747159

Van DuZer C. A. 2013. - Sea Monsters on Medieval and Renaissance Maps. The British Library, London, 143 p.

Veracini C. 2011. — La conoscenza dei Primati nell'Europa Rinascimentale. Ph. D. Thesis, Department of Philosophy. University of Pisa, $162 \mathrm{p}$.

VERACINI C. \& CASANOVA C. in press. - How non-human primates and other terrestrial West African mammals were described in the Portuguese literary sources of the $15^{\text {th }}$ and $16^{\text {th }}$ centuries. Proceedings of the 7th Conference of the Italian Association of Zooarchaeology, Ferrara, 2012.

Williams M. I. \& STEADMAN D. W. 2001. - The historic and prehistoric distribution of parrots (Psittacidae) in the West Indies, in Woods C. A. \& Sergile F. E. (eds), Biogeography of the West Indies. CRC Press, Boca Raton: 175-189.

Zambon F. (ed.) 1975. — Il Fisiologo. Adelphi Edizioni, Milano, $162 \mathrm{p}$.

ZekÂI OKTe E. \& Duran T. 1988. - Kitab-I Bahriye Pirî Reis. 1. The Historical Research Foundation, Istanbul Research Center, Istanbul; Ministry of Culture and Tourism of the Turkish Republic, Ankara, 903 p.

ZuRARA G. E. 1937. - Cronica do descobrimento e conquista da Guiné. Livraria Civilização, Porto, 568 p.

\section{MAPS}

AnONYMOUS $12^{\text {th }}$ century. - Creation of animals, mappamundi. (MS 8f. 12v). Topkapi Sarayi, Istanbul.

ANONYMous 1375. - Catalan Atlas. (MS Espagnol 30). Bibliothèque nationale de France, Paris.

Anonymous 1502. - Planisphere, (The Cantino). Biblioteca Estense, Modena.
BeHaim M. 1492. - The Erdapfel, Mappa Mundi. German National Museum, Nuremberg.

Bry T. DE 1599. - Map of Guiana. America, Part 8. Frankfurt on the Main. http://www.davidrumsey.com/luna/servlet/detail/RU MSEY -8 1 -203959 -3001742:Facsimile--Guiana-by-de-Bry last consultation: 17/05/2016.

Савот S. 1544. - World Map of A. D. 1544 (the Sebastian-Cabot map). Bibliothèque nationale de France, Paris.

De La Cosa J. 1500. - Manuscript map. (93 × $183 \mathrm{~cm}$ parchment $)$. Museo Naval of Madrid, Madrid.

GaSTALDI G. 1561. — Gastaldi's World Map. Cosmographia universalis (Venice)

Haldingham AND LAFFORD R. OF C. 1300. - Mappa Mundi. "Cloth of the World". Hereford Cathedral, Hereford. http://www.herefordcathedral.org/visit-us/mappa-mundi-1 last consultation: 17/05/2016.

Higden R. 1363. - Polychronicon. World map. British Library, London.

Homem L. c. 1519. - Planisphere, Atlas of the World, The Miller Atlas. Bibliothèque nationale de France, Paris.

LE TeSTU G. 1555. - Cosmographie Universelle selon les Navigateurs, tant anciens que modernes. Bibliothèque nationale de France, Paris.

Martellus Germanus H. c. 1498. - World map, in Henricus Martellus Germanus's Insularium Illustratum. Beinecke Rare Book and Manuscript Library, Yale.

Mecia De VILAdestes 1413. - Portulan chart. Bibliothèque nationale de France, Paris.

Mercator G. 1569. - Nova et Aucta Orbis Terrae Descriptio ad Usum Navigantium Emendate Accommodata. Bibliothèque nationale de France, Paris.

ReIs P. 1513. - Pîrî Reis Haritasi. The World Map (1513). (No. H. 1824). Library of Topkapi Sarayi Muzesi, Instabul.

ReIS P. 1528. - The Second World Map (1529). (Revan 1633). Topkapi Sarayi Muzesi, Instabul.

Ribeiro D. 1529. - Planisphere. Biblioteca Apostolica Vaticana, Rome.

RibEIRO D. 1532 - Chart of America, the Pacific, and the Far East. (Cod. Guelf. 104 A und B Aug. fol.). Herzog August Bibliothek, Walfenbuttel.

WALDSEEMÜLlER M. 1507. — Universalis Cosmographia Secundum Ptholomaei Traditionem et Americi Vespucii Alioru[m]que Lustrationes, [St. Dié]. One map on 12 sheets. Geography and Map Division, Library of Congress, Washington D. C.

Waldseemüller M. 1516. - Carta Marina. Jay I. Kislak Collection at the Library of Congress, Washington D. C. 